\title{
OMNIPRESENCIA DE LA CENSURA EN LA ESCRITORA ARGENTINA
}

\author{
POR \\ REINA ROFFE \\ Montclair State College
}

\section{Estado de CENSURA}

En un gobierno constitucional y popular, la libertad de expresarse sin restricciones es condición esencial de la dinámica y el avance del pensamiento; la crítica constituye un vehículo propicio para el desarrollo de la cultura. En la Argentina de estos últimos diez años - más que en otros períodos-, la vigencia del derecho quedó suspendida. El escritor padeció las secuelas de una época de violencia que se manifestó en diversas formas. Una de ellas fue la censura - arma corriente de los regímenes dictatoriales y minoritarios-, que vulnera el principio de la libertad y de la creación y que hace tambalear el futuro de un país, fracturando su continuidad cultural y generacional.

En los trágicos años de la dictadura, nadie sabía a ciencia cierta quiénes eran los censores; de qué manera se regían para prohibir los libros de literatura, historia, sociología, psicología, filosofía, política y aun de matemáticas. Lo único que resultaba obvio era la ignorancia y desconocimiento de éstos con respecto al material que reprobaban. En este sentido, la Inquisición en la Edad Media fue menos tapada, más sabia y mucho más coherente que el tribunal fantasma que, desde el 76, funcionó en la Argentina. Una disposición, que muchas veces no llevaba firma de institución o de persona alguna, bastaba para que una obra - ya sea por su título, una frase o porque el autor no era persona grata para el régimenfuera inmediatamente retirada de circulación. Hay que recordar que las Ligas de moralidad que proliferaron en la época se encargaron muy bien de realizar pesquisas diarias por las calles infundiendo terror entre editores y libreros y provocando, de esta manera, una verdadera psicosis. El escritor se vio acuciado no sólo por la censura del Estado, sino por un 
estado de censura. Los editores y libreros, ante posibles sanciones, prefirieron publicar y vender libros extranjeros de consumo. Gran parte de los lectores, por fuerza mayor, debieron «limpiar» sus bibliotecas y optar por el facilismo del típico best-seller americano o del love-story local, evitando, de este modo, riesgos y pensamientos perturbadores. Así se creó lo que podríamos denominar paracensura, la cual incrementó y desarrolló en el escritor diferentes mecanismos de autocensura.

En ciertos procesos históricos quedan al descubierto de manera clara los elementos más represivos que actúan sobre el arte, ya sea para silenciarlo o para que funcione como instrumento de propaganda oficial. Esto es posible cuando la ideología imperante de un pueblo o de un amplio sector de ese pueblo responde a un sistema de valores que, por no haber sido cuestionado a fondo, se identifica con el del opresor. «El autoritarismo argentino - dice Sebreli- no es tan sólo una organización política determinada, está disperso, impalpable, en la sociedad civil, en el estado de ánimo de la gente, en los hábitos y costumbres, en la atmósfera, un poco diluido en todas partes, en todas las cosas» ${ }^{1}$. Los argentinos han sido sometidos desde siempre a presiones totalizantes: dominación económica, fanatismos políticos, escisiones sociales, manipulación cultural, que contribuyeron a la confusión de sus conciencias. De ahí que los militares hayan encontrado margen de maniobra para erigirse y asumir todos los poderes del Estado y otros con los que llevaron a cabo un sistemático genocidio. $\mathrm{Y}$, en cuanto al tema que nos concierne, pudieron prohibir con impunidad toda literatura disidente o molesta para sus consignas morales, secuestrar, censurar y proscribir no sólo los libros, sino a los autores; mientras tanto, permitieron y alentaron aquella otra literatura que, aunque aparentaba una protesta, en realidad justificaba el golpe y era vocera de la Junta ${ }^{2}$. Literatura que, tal vez por el vacío producido, recibió el elogio de la crítica y fue leída profusamente, encabezando la lista nacional de los más vendidos durante casi todo el proceso. Hecho que de alguna manera demuestra hasta qué punto la represión y el lavado de cerebro fueron efectivos.

La crisis en la Argentina ha sido individual y social, porque el crecimiento de una sociedad depende del crecimiento de los hombres y de las mujeres que la componen. Evidentemente, la emancipación cultural no será posible hasta que no se detecten las causas que generan opresión y

1 Juan José Sebreli, Los deseos imaginarios del peronismo (Buenos Aires: Editorial Legasa, 1983), p. 187.

${ }^{2}$ Véase el artículo «Best-seller y código represivo en la narrativa argentina del ochenta: el caso Asís», por Andrés Avellaneda, en Revista Iberoamericana, Pittsburgh, vol. XLIX, núm. 125 (octubre-diciembre 1983), p. 983. 
aceptación de subordinaciones políticas, sociales y económicas, hasta que no se expulsen definitivamente las dictaduras, hasta tanto los individuos no sean capaces de transformarse en seres adultos e independientes.

\section{SITUACIÓN DEL ESCRITOR}

La censura pone al escritor en situaciones límites: 1) lo silencia, interrumpe sus itinerarios creativos, frustra su vocación de escribir y de expresarse; 2) corrompe su lenguaje, lo fuerza a inventar eufemismos o a negar la realidad; 3) lo obliga a emigrar de su país, a vivir y crear en un medio ajeno. Un escritor no puede trabajar bajo la presión del miedo o de la autocensura, que es hija directa de la censura. Tampoco es recomendable que especule con las palabras y los hechos para sobrevivir en un ámbito hostil a la verdad; rechazar toda escritura complaciente debe ser inherente al escritor. Es factible que éste pueda desarrollarse en cualquier parte del mundo que le ofrezca posibilidades, pero salir del país - sobre todo por razones colaterales a su auténtica voluntad - no deja de ser motivo de permanente angustia; los desplazamientos implican alejarse de las raíces, de una identidad nacional y, por ende, idiomática.

Además de la censura que es habitual en sociedades dependientes y de la exacerbación de ésta instrumentada por los gobiernos de facto, existe una menos directa o detectable, pero más efectiva y permanente, que recae en la mujer que escribe. Escritoras de todos los tiempos han vivido bajo la omnipresencia de la censura como resultado de la marginación en que la tradición patriarcal y machista colocó a la mujer.

Para dedicarse a escribir, muchas han tenido que encerrarse en un convento, como Sor Juana; ponerse «más allá» del ojo censor de su sociedad. Para mostrar el producto de su obra, otras han debido vencer - como Jane Austen - el pudor que la llevaba a ocultar su manuscrito debajo de un secante cuando alguien entraba a su cuarto; a cubrir las pruebas de un delito de pecado. Para publicar, algunas han recurrido a los subterfugios del seudónimo y/o atuendos masculinos, como la francesa George Sand y la argentina Emma de la Barra/César Duayen, escapando así de la sanción atávica destinada a su sexo en cuanto a la creación. Y, cuando publicaron, todas se han visto objetadas por una crítica que descalificó sus textos considerándolos triviales, demasiado anecdóticos o sentimentales y que, en general, no supo ver más que «algunos valores» propios de lo que han denominado en forma maniquea «literatura femenina».

Se podría decir, por la cantidad de escritoras y el éxito que han tenido y tienen en la Argentina, que ninguna parece haber sufrido los tipos 
de censura y autocensura de Sor Juana, Austen y Sand. Pero éxito no debe confundirse con reconocimiento; tampoco se debe creer que éste es el indicador de una sociedad equitativa que acepta plenamente la participación de la mujer en el panorama cultural, cuando los gustos, costumbres y mitos de esa sociedad están orientados y estimulados hacia una posición autoritaria. Sabemos que el Occidente, regido por los cánones de la Iglesia, ha fundado su discurso de acuerdo a un orden de censura. El hombre que escribe se ve enfrentado a la ley, pero la mujer no sólo a la ley, sino a la autoridad representada por el hombre, que es el que tiene el monopolio de la palabra -en la Argentina, y todavía-. ¿Acaso no es significativo que haya sido a partir de los cincuenta cuando ha comenzado a tomar auge la narrativa escrita por mujeres? Hasta entonces la mujer estaba confinada a la poesía porque este género se ajustaba más a su «sensibilidad». La poesía, hecha de imágenes y metáforas, pasaba inadvertida; en cambio, la narrativa, que es la que cuenta y da testimonio del mundo en que se vive, presenta un desafío directo. Narrar es significar, entrar en otro terreno, meterse en un territorio prohibido, en la propiedad del autor. Tal vez por eso - y a pesar de ser conocidas, porque aparecen en los medios de comunicación y se las invita a programas de radio y televisión, a mesas redondas y conferencias-, siempre son atacadas por sus posiciones políticas o clasistas y sus obras "censuradas» por razones extraliterarias. Es frecuente oír a algunos escritores decir que Fulana es una reaccionaria o una señora gorda, que escribe con los pies y sobre lo primero que le viene a la mente; pero casi ninguno de ellos ha leído sus libros. Estos prejuicios, y este ojo crítico que siempre mira mal, que desconfía y que escatima el verdadero reconocimiento, se suman a la lista de presiones que ejerce el medio sobre y en la cabeza de las escritoras.

Las escritoras éditas tampoco reconocen su escritura. Cuando se les ha preguntado, en reportajes y encuestas, si existe una literatura femenina, si pueden señalar alguna diferencia entre la escrita por mujeres y la hecha por hombres, las respuestas de la mayoría son esquivas; en general niegan toda diferenciación, sin advertir que censuran un sistema expresivo que está, como dijo Marta Traba, «fuertemente potenciado por una experiencia particular, de percepción, elaboración y proyección» ${ }^{3}$.

En 1977, en una nota del diario Clarín ${ }^{4}$, una escritora manifestó que descree que haya una literatura femenina argentina y que, a lo que se

3 Marta Traba, «Hipótesis sobre una escritura diferente», en revista Quimera, Barcelona, núm. 13 (noviembre 1981), p. 9.

${ }^{4}$ Véase el artículo «¿Existe una literatura femenina?», por Liliana Heker, en Clarín cultura y nacion (Buenos Aires, 12 de mayo de 1977), p. 1. 
pueda llamar así, aporte o añada algo a la literatura nacional. Menos contundente, pero igualmente sugestiva, fue la opinión de Silvina Ocampo, que dijo: "A veces pienso que en la literatura escrita por mujeres pululan mis defectos y en la escrita por hombres otros defectos menores, ya que no son los míos, pero prefiero no tomar en cuenta el sexo de lo que estoy leyendo. Cuando se trata de perros, confieso que averiguo el sexo del perro que se acerca, si estoy en la calle con mi perra, y si es del mismo sexo trato de evitar el encuentro, porque las perras se odian a muerte y me duele la violencia de los que se odian, ya sean hombres o animales» ${ }^{5}$. Esto nos remite al problema de la competencia, que involucra tanto a hombres como a mujeres, pero que en nuestro caso es más patético. La presión social obliga a la mujer a que cuando encuentra un lugar tenga que imponerse y afirmarse con uñas y dientes. Lo que a veces olvidamos es que hay lugar para todos y en un estado de igualdad cada uno debería ocupar el que le corresponde. Negar al otro o el lugar del otro es también una forma de censura interna y externa; es negarse a uno mismo. La mascarada de hacer creer que se cree en la inexistencia de una literatura femenina responde a un acto de autodefensa y es a la vez un intento, por parte de las escritoras, de afianzamiento. Durante muchos años, la crítica -dedicada más bien al comentario que al análisis de los textoshabló de literatura femenina en términos peyorativos, considerándola menor. El «malentendido», que sirvió para descalificar la irrupción cada vez más creciente de la mujer en la literatura, repercutió de tal manera que muchas escritoras han tratado, en lo posible, que no se las identifique con el feminismo ni con nada que las margine más y las haga aparecer «desagradables», «enfermizas» o «peligrosas» ante la mirada de su sociedad.

Las escritoras inéditas o las que están en el comienzo de su carrera han recibido el bagaje de una serie de dichos y entredichos: la escritura femenina carece de nivel simbólico; está sujeta al referente porque la mujer necesita contar y contarse, entender y que la entiendan; abusa de repeticiones, interrogantes y detalles; se caracteriza por un tono de enojo, resentimiento, etc., como si todo esto fuese, por un lado, aberrante $\mathrm{y}$, por otro, defecto exclusivo de las mujeres. A la hora de escribir, estos estigmas, que han calado hondo, aterrizan en la mesa de trabajo y suscitan cierta parálisis, ciertos miedos frente a la hoja en blanco. La autocensura que anula también produce engendros; es cuando la mujer, buscando aprobación, renuncia a lo que tiene que decir y toma una voz prestada

${ }^{5}$ Véanse las respuestas de Silvina Ocampo en la entrevista realizada por Noemí Ulla, Clarín cultura y nación (Buenos Aires, 12 de mayo de 1977), p. 2. 
que, al no pertenecerle, se vuelve contra ella misma. La tentación, por momentos inconsciente, de responder a las expectativas y exigencias del medio, de la crítica y de interlocutores que funcionan como marco de referencia intelectual, son esfuerzos que se realizan para salir de una situación de inferioridad, pero a veces no hacen más que estancar el proceso creativo.

La cantidad de libros y artículos sobre la cuestión de la mujer y de la escritora que han circulado últimamente, abriendo un canal de acercamiento al problema, ofreciendo una vía de análisis que ha llevado a pensar y entender la literatura hecha por mujeres como un proyecto alternativo, un nuevo discurso que ya está en marcha. Discurso que nace de una sensibilidad y de una imaginación críticas en repudio a todo lo que oprime. Desde la reconstrucción de las diferentes etapas de la vida; desde esas zonas que lindan o ahondan en el amor y el delirio; desde una visión introspectiva pero abarcadora del universo, pasando por las instancias del descubrimiento sexual y erótico; y desde el resentimiento que se invierte a hecho positivo, esta escritura reacciona transformativamente. No podía ser de otra manera: en la lucha por conseguir una voz se observa la dimensión del sometimiento; en la batalla es donde esta escritura comienza a reconocerse. Cuando las escritoras figuren más en antologías y empiecen a ser leídas por todos; cuando la crítica deje definitivamente de referirse al sexo como una forma de escamotear el texto y la mujer que escribe no llame la atención por este solo hecho; cuando su capacidad y talento no sean catalogados como excepcionales o ellas como casos aislados, entonces las censuras serán desplazadas por la búsqueda de los valores intrínsecos de la obra y la escritora hallará un lugar incuestionable.

\section{Testimonio}

En 1976, a los dos meses de aparecer en la Argentina mi segunda novela, titulada Monte de Venus, una disposición municipal prohibió el libro en Buenos Aires por razones de inmoralidad; más tarde lo prohibieron en todo el país. El rótulo de inmoral encubría otro asunto. En Monte de Venus cuestiono el sistema educativo; develo algunos aspectos por los cuales los personajes sufren frustraciones sexuales y políticas y, por lógica consecuencia, marginación; abordo el tema de la mujer: su vinculación con el cuerpo, con el hombre, su vida cotidiana y los interrogantes que se le presentan acerca de su propia naturaleza. Las protagonistas no sólo se preguntan por ellas mismas, sino por la historia que las hace o deshace como criaturas humanas. La novela acusa recibo de corrientes contradic- 
torias: la de una coyuntura política que parecía otorgarle a la mujer cierto poder y que luego fue revelando su carácter ilusorio. Un período que a estas mujeres les recuerda aquello del Gatopardo: todo tiene que cambiar para que nada cambie. Temas intolerables para una sociedad que se niega a aceptar la falacia en la que vive. Por eso también fue intolerable el título que alude al sexo femenino. Si muchas veces los censores han caído en la arbitrariedad de impugnar una obra de Shakespeare o de otros clásicos, ¿qué podía esperar una escritora nacional precisamente cuando los militares se autoproclamaban guardianes de la moral y las buenas costumbres e iniciaban la etapa de devastación argentina?

Durante el tiempo que el libro estuvo en las librerías, los críticos sacaron algunas notas; los reporteros me entrevistaron; el editor invertía, dentro de la precariedad económica del momento, algún dinero en publicidad. Pero inmediatamente después de la prohibición, o mejor dicho, un poco antes -cuando se corrió el rumor de que Monte de Venus era "provocativa» $y$, por tanto, destinada a caer bajo la picota de la censura-, el periodismo me silenció; el editor no sólo hizo desaparecer del depósito los ejemplares que quedaban, sino que al libro y a mí nos eliminó del catálogo; los libreros apuraron las devoluciones, y hasta los amigos escogieron no mencionar la novela. Por otro lado, algunos señores se me acercaron para averiguar con mucha curiosidad cuán «inmoral» era yo; y ciertas señoras se alejaron de mí ni bien se enteraron de que era una escritora prohibida, alguien que podía comprometerlas o contagiarlas de quién sabe qué rara peste.

Indignación e impotencia configuraron en mí el sentimiento de haber sido violada, pues se me había amordazado para luego denigrarme. Cometer una violación es penetrar sin ningún derecho, es ajar, deslucir una cosa o a alguien, pero aún más: profanar la integridad. Sentirse violento en un lugar es no estar a gusto, y yo no podía sentirme a gusto en el sitio que me habian designado. Si escribir es salir de la oscuridad, de la isla personal para ir al encuentro de otra luz, de otras voces, en ese momento no valía la pena: dejé de escribir por mucho tiempo.

Finalmente, cuando advertí que yo también me había rendido a la indolencia, que diversas manifestaciones de censura - las reales y las subterráneas- se estaban internalizando al extremo del sabotaje, y que mi ensimismamiento no hacía más que agregarse al silencio perpetuador de la derrota y el desgarramiento, volví a mis papeles. En la escritura, que es de por sí transgresiva, la escritora halla siempre y a pesar de todo el curso vital de la lucha. 
